\title{
REFLECTING THE THEATRALIZATION OF LIFE IN THE PROSPECTS OF TRANSHUMANISM
}

\author{
Lada Prokopovych \\ Department of Art History Cultural Studies and Philosophy of Culture \\ Odessa Polytechnic State University \\ 1 Shevchenko ave., Odessa, Ukraine, 65044 \\ lada.prokopovich@gmail.com
}

\begin{abstract}
The crisis state of society at the beginning of the 21 st century is increasingly described as chaos. At the same time, the desire of people to theatricalization of many types of their activities remains unchanged. This gives grounds to consider the theatricality of being as a sociocultural constant, immanently inherent in humanity. The fact that it persists even during periods of cardinal changes, social transformations, civilizational shifts, breaking cultural stereotypes, destruction of traditional institutions and discreditation of established ideals can be explained by the fact that theatricalization of life allows people to cope with sociopsychological discomfort and existential fears, caused by the feeling of total chaos. At the same time, people are faced with the problem of increasingly complex self-identification, which is largely facilitated by the ideas of transhumanism, which actively shatter the already weak notions of what a human being is. One of the approaches to solving this scientific problem is proposed to consider human activity in the context of theatricality of being.

The purpose of the article is to comprehend the practice of theatricalization of various types of human activity in the context of the ideas of transhumanism. The methodological strategy of this research is based on the concept of theatricality of socio-communicative manifestations of culture. Analysis of the theoretical material showed that in the conditions of transhumanism, the development of criteria that make it possible to determine whether a human is still a human or has already turned into something else becomes an urgent task. One of these markers is proposed to consider the desire of a human to theatricalization of various types of their activities. Being one of the sociocultural constants immanently inherent in humanity, theatricality will be present in people's lives as long as they remain human, as long as they feel the need to articulate their social communication.

Keywords: transhumanism, theatricalization of life, play, social communication, philosophical performance "In the Circle of Light. Improvisation in antique style".
\end{abstract}

DOI: $10.21303 / 2504-5571.2021 .001972$

\section{Introduction}

The sophisticated complex of crises (economic, epidemiological, political, social, cultural, semantic, value, etc.), in the conditions of which mankind found itself at the beginning of the XXI century, is increasingly described as chaos ("social chaos" [1, 2], "controlled chaos"[3], etc.). At the same time, the desire of people to theatricalization of many types of their activities remains unchanged. This gives grounds to consider the theatricality of being as a sociocultural constant, immanently inherent in humanity. The fact that it persists even during periods of cardinal changes, social transformations, civilizational shifts, breaking cultural stereotypes, destruction of traditional institutions and discreditation of established ideals can be explained by the fact that theatricalization of life allows people to cope with sociopsychological discomfort and existential fears, caused by the feeling of total chaos. The basis for this is the understanding that theater always presupposes the presence of a director, scenarios, laws of genre and other components that allow us to hope that there is still some kind of plan, and not everything is as uncontrollable, unpredictable, meaningless as it seems [4].

Unfortunately, it is becoming more and more difficult for people to cope with the feeling of the increasing chaos of life, which is largely facilitated by the ideas of transhumanism, which are actively shaking the already weak notions of what a Human, inherent to a human, is.

The situation is paradoxical: without fully understanding what a "human" is, we, nevertheless, undertake to improve it.

Therefore, the ideas of transhumanism and attempts to implement them in practice not only face sharp criticism from scientists, warning about the unpredictability of the results of any inter- 
vention in human nature [5], but also lead to the need to comprehend (additionally reflect? rethink?) human nature, its defining qualities and abilities ... This is especially true in connection with the introduction of such concepts as "transhuman", "posthuman" [6] and even "service human" [7].into the scientific discourse.

One of the approaches to solving this scientific problem can be the consideration of human activity in the context of the theatricality of being.

The purpose of this study is to comprehend the practice of theatricalization of various types of human activity in the context of the ideas of transhumanism.

\section{Materials and Methods}

The methodological strategy of this research is based on the concept of theatricality of socio-communicative manifestations of culture [4]. Within the framework of this concept, the theatricality of being is understood as the artistic and playful component of the assimilation (comprehension, interpretation, transformation) of socio-cultural reality in the life of a human and society. Sociocommunicative manifestations of culture are defined as the actualization of cultural phenomena (processes, practices, products) through social communication.

\section{Results}

The concept of "theatricality" is directly related to the concept of "performativity".

Understanding the essence of performativity as a combination of utterance and action with demonstration of what is being said allowed Judith Butler [8], Ewa Domanska [9] and other researchers to introduce this concept into philosophical, social, political science discourses, offering it as a method, with which one can analyze actions, events, social gestures, etc. An American theater anthropologist Richard Schechner, in his work "Essays on Performance Theory" (1970-1976), expanded the concepts of "performativity" and "theatricality" to their manifestations in everyday life. At the same time, he paid attention not to cases of theatrical performance, which arises as a result of a human performing different social roles, but to certain repeated rituals, behavioral patterns, into which a human entered automatically, unmistakably determining how to behave in a particular situation [10]. Jürgen Habermas considered performativity as a condition for the exisi tence of individuality in communication, as a means of self-knowledge and a way to evoke understanding on the part of other participants in communication. In this sense, a performative "text" does not so much speak about something as it shows something, that is, it accompanies what is said by the execution [11].

The concepts of "theatricality" and "performativity" are also associated with such a concept as "play". Most researchers agree that play is a sociocultural phenomenon inherent exclusively in human activity. Johan Huizinga, for example, argued that play is a necessary element of social life, which determines the essence of spiritual culture, is a meaningful form that carries meanings [12]. Friedrich Schiller said that a human plays only when he/she is a human in the full sense of the word, and he/she is completely human only when he/she plays [13].

The social aspect of theatricality, performativity, play as elements of the sociocultural activity of people and a special form of relations and communication has been considered by many researchers. Hermann Hesse pointed out that the game gives a human the opportunity to find him/herself, thanks to the "playing" of the thousand faces that are concentrated in him/her alone [14]. Gilles Deleuze put forward the idea of theatrical laws of the world order [15]. Guy Debord interpreted social relations through the prism of the concept of "society of the spectacle" [16]. Erving Goffman developed a "dramatic" approach for sociological analysis of human behavior in various life situations [17]. Mark Lipovetsky explored the functions of the Trickster as a "character" in social and political "theater" [18]. Yuri Lotman, revealing signs of theatricality in life, said that "life chooses art as a model and hastens to" imitate "it" [19]. Anatoly Bakanursky, studying the mask as one of the constructs of the theatricalization of life, argued that the mask allows a human to be in a state of otherness for some time, that is, to be not him/herself, thus satisfying one of the important needs of the individual [20]. Hanna Chmil and Nadiia Korablova use the theory of social roles to comprehend a new cultural reality, which they propose to consider precisely as a role-playing reality [21]. 
Andrew Olyanich suggests exploring politics and social communication in the discourse of ritual drama [22]. The generalization of these ideas, views and approaches allows us to talk about the theatricalization of life as a widespread social and cultural practice.

The practice of theatricalization of life lies in the fact that in different types of their activities people bring elements of theater - play, artistry, direction, drama, scenography. In social communications, this helps to solve many different life problems. Therefore, elements of theatricality are found in politics [23], education [24], sports [25], the museum sphere [26] and even in robotics, more precisely, in the practice of using robots [27].

This can be explained not only by the eternal desire of people to play, but also by ample opportunities for creative experiments.

The scientists of Odessa (Ukraine) decided on one of such experiments, having carried out a philosophical performance "In the Circle of Light. Improvisation in antique style".

Nine women scientists from different universities of Odessa took part in the project: Inna Golubovych, Dr. of Philosophy Sciences (Odessa I. I. Mechnikov National University); Olga Gornyak, Dr. of Economic Sciences (Odessa I. I. Mechnikov National University); Елена Лисеенко, Dr. of Sociological Sciences (The State Institution "South Ukrainian National Pedagogical University named after K. D. Ushunsky"); Ella Mamontova, Dr. of Political Sciences (National University “Odessa Law Academy”); Svitlana Ovcharenko, Dr. of Philosophy Sciences (Odessa Regional Institute for Public Administration of the National Academy for Public Administration under the President of Ukraine); Valentina Podshyvalkina, Dr. of Sociological Sciences (Odessa I. I. Mechnikov National University); Lada Prokopovych, Dr. of Philosophy Sciences (Odessa Polytechnic State University); Natalia Rodina, Dr. of Psychological Sciences (Odessa I.I. Mechnikov National University); Olga Yushkovska, Dr. of Medical Sciences (Odessa National Medical University).

The participants discussed the ancient origins of culture and science, the eternal questions of our time, and positive scenarios for the future in the format of an ancient Greek symposium. The participants were inspired by the collection of clothes and accessories "Elena the beautiful", created by the Odessa designer Elen Godis, to this format and topic of discussion. "Antiquity is perhaps the best thing that has happened to humanity," says Elen Godis. - Golden Age. Earthly beauty and harmony of nature, art, human body. The cult of morality, nobility, correct behavior, which lead a human to harmony of physical and spiritual perfection. This is how I see our distant past. And this is how I want to see our future. The collection of images, presented in this project, was created with ease and inspiration. This is a bridge connecting the eras, making you feel like the beautiful Elena".

Such an intellectual and spiritual message could not be ignored by the representatives of modern science. Having decided that this idea deserves not only visualization, but also development in the format of scientific discussion, the professors, dressed up in costumes from Elen Godis, appeared before the public in the images of ancient Greek goddesses.

The transformation of university teachers into ancient (but modern) goddesses made it possible to create a specific atmosphere of communication. Elen Godis saw this as her mission - "to bring different women scientists together and give them the opportunity to present themselves as goddesses. Because when a human feels him/herself in a certain way, he/she thinks accordingly".

The effect of "being in antiquity" was enhanced by the environment: the performance was held in one of the halls of the Museum of Western and Eastern Art, among the exhibits demonstrating the features of ancient art.

Another goal of this project was formulated by Inna Golubovych: "Science, scholarship, spiritual culture is a game. And we also wanted to introduce this motive. We want to show a new face of science, a new face of the cultural industry, which is usually perceived as entertainment. But in reality it is a resource, a reserve, a generator of ideas. "

It should be noted, that both goals have been achieved. It was the theatrical nature of the project that made it possible to combine things that rarely come together - a fashion show and a philosophical round table. And this, in turn, made it possible to combine intelligence and beauty, material and spiritual, traditions and innovations. Stretching the "thread of times" from antiquity to the present, the participants tried to look into the future from the perspective of the sciences they represented. 
Inna Golubovych proposed to set a new "optics" for the knowledge of the world, including the method of "love contemplation". After all, the method is the path, more precisely, the path of the future. And then the truth will open to us that to see the world and to know it means to love, care, feel tenderness, gratitude, dance, play and rejoice. This method will allow modern philosophy to reach a new understanding of the world and human.

Valentina Podshyvalkina sees the society of the future as a society of free, self-determined, wise individuals who understand their freedom in the highest manifestation of responsibility.

Ella Mamontova talked about the formation of a "dream society" where impressions become the main resource. But from different scenarios for the development of states, the tendencies of which are already visible and comprehended by modern political science, we must choose the one that will allow them to develop, while maintaining independence in decision-making.

Olga Yushkovska is convinced that medicine with a new understanding of the value of human life will allow humanity to survive, in the name of health, in the name of harmony of the body, beauty and intelligence.

Natalia Rodina sees the future as a world, in which people will feel comfortable and prosperous. In this world, humor (as a sign of psychological well-being), self-esteem and respect for other people, a sense of joy from every moment of life will certainly be present.

Elena Liseenko said that the future can and should be designed just now. And this is within the power of every human who can choose his/her own social roles, becoming the creator of his/her life. This creativity should be carried out taking into account such values as humanity, wisdom, love.

Olga Gornyak pointed out that the economy of goods has exhausted itself. It should be replaced by the human economy, which involves investment not in things, but in a human, in his/her development.

Svitlana Ovcharenko noted that researchers of modern culture have come to the understanding that there is no middle, universal human who Western culture has been guided by for many years. Humanity is divided into many individuals. Therefore, the world of the people of the future will be infinitely diverse, but at the same time - whole. The main challenge is to preserve cultural diversity.

In general, without offering any detailed scenarios (this is impossible in such a rapidly changing world), each of the participants outlined the general directions, in which humanity should move, so that its future turns out not to be gloomy and hopeless, but positive, focused on human development in harmony with society, technology and nature.

\section{Discussion}

The theatrical character of the project "In the Circle of Light. Improvisation in antique style" was due (among other things) to the fact that theater, as a phenomenon of European culture, originated precisely in antiquity. As an art form, it emerged from the ancient Greek mysteries, dedicated to the gods of fertility - Dionysus, Demeter, Persephone [28]. But if ritual performance prevailed in the format of the mysteries, then when moving to the stage, the main element of drama was dialogue (between characters, between the main character and the choir).

But dialogues exist not only on the theatrical stage, but also in life. Moreover, dialogue is the main form of social communication. There are dialogues that connect individuals to society.

And if, where there is a theater, there is a dialogue, then it is logical to assume that where there is a dialogue, a theater should also arise. In fact, this is how it happens: in any communication where there is a conditional "actor" and an audience, elements of theatricality appear. In some acts of communication, theatricality is more pronounced, in others it is less, but it is always present. Actually, this fact allows us to consider theatricality as one of the sociocultural constants in the being of mankind.

Therefore, the question arises: Will the "posthuman", cultivated by transhumanists, need the dramatization of social communication?

After all, it is clear that if a human changes, then society will also change. But what will it be?

Irina Melik-Gaikazyan notes that in a state of social instability, the phenomenon of dreams with ideas about the desired future acquires special force. Such a dream is reflected in the utopian 
ideas that are proposed by projects of social restructuring [29]. Alexander Oslon also speaks about the same, noting that among human's ideas about the structure of the world, - inhabited by things, phenomena, ideas, living beings, including people, - ideas about the future occupy a special place. These representations play the role of a kind of prism, through which the present is viewed, and on which the understanding of what now needs to be recognized as important and what should not be paid attention largely depends [30].

The ideas that are generated in the discourse of transhumanism force us to approach with heightened responsibility the definition of what should be recognized as important, valuable for the life of each individual human and the society, in which he/she lives.

The tendencies that have emerged in transhumanism can lead not so much to the improvement of a human as to the destruction of society. After all, if, for example, there are no illnesses, then there will be no sympathy, no desire to help, save. If there is no help, support, mutual assistance, there will be no gratitude. If all people are the same, then on what basis will sympathy, friendship, love grow? And if there are no emotions, then why would an improved memory be needed? After all, a human needs memory in order to store not only information, but also life experience. What will the life experience of an improved human be made of? And by the way, is the improvement, a complication or a simplification?

But the main question is not how it will be, but how far it can go. At what stage will it be necessary to state that a human is no longer a human, but something else? What criteria will be used to determine this?

In any future scenario, the tendency of people to theatricalization of life can be one of the markers that make it possible to determine whether a human is still a human, or has already turned into a biorobot. Into a certain digitized, programmed, imhumanal unit of some global system, in which there is no place for irrationality, doubt, conflict, fantasies, dreams.

As long as we feel the need for live communication with other people, as long as we retain a craving for creative experiments, play, adventures, we will carry out them, introducing elements of theatricality.

Therefore, the identification of these elements should become one of the directions in the future research of the transformation of human and society. In the context of transhumanism, this will allow either to trace the moment of disappearance of theatricality from people's lives, or to fix the formation of some other form of it - trans-theatricality - with other cultural and social goals.

\section{Conclusions}

Despite the fact that the theory of transhumanism is controversial and poorly argued, it is actively implemented in practice, ignoring criticism and increasing the number of adherents. Therefore, comprehension and forecasting of further transformations of human and society should be carried out taking into account this tendency.

Then the task of developing criteria that makes it possible to determine whether a human is still a human or has already turned into something else comes to the fore. The desire of a human to theatricalization of various types of their activities is proposed to consider one of these markers. Being one of the sociocultural constants immanently inherent in humanity, theatricality will be present in people's lives as long as they remain humans, as long as they feel the need to articulate their social communication.

\section{References}

[1] Budanov, V. G., Aseeva, I. A. (2013). Social Chaos and Problems of Management of Future During an Era of Changes. World Applied Sciences Journal, 25 (9), 1383-1389.

[2] Pavlov, A. P., Pavlov, P. A. (2015). Ontology of social chaos. Gramota, 8 (58), 136-139.

[3] Manoylo, A. V. (2014). Role of controlled chaos strategies in the formation of the new global order. Law and Politics, 5 (173), $638-651$. doi: http://doi.org/10.7256/1811-9018.2014.5.11816

[4] Prokopovich, L. V. (2019). Theatricality in socio-communicative manifestations of culture: a socio-philosophical study. Odek sa: Ekolohiia, 336.

[5] Bostrom, N. (2005). A History of Transhumanist Though. Journal of Evolution and Technology, 14 (1). 
[6] Fereidoun, M. (1989). Are You a Transhuman? Monitoring and Stimulating Your Personal Rate of Growth in a Rapidly Changing World. FM-2030. Warner Boors, 227.

[7] Vladimirov, D. (2020). Mikhail Kovalchuk: «Kolonizatsiya zamenilas tekhnologicheskim poraboscheniem». Argumenty i fakty. Available at: https://aif.ru/society/opinion/mihail_kovalchuk_kolonizaciya_zamenilas_tehnologicheskim_poraboshcheniem

[8] Butler, J. (1998) Hass spricht: Zur Politik des Performativen. Berlin: Berlin Verlag, 159.

[9] Domanska, E. (2012). Istoriia ta suchasna humanitarystyka: doslidzhennia z teorii znannia pro mynule. Kyiv: Nika-Tsentr, 264.

[10] Shechner, R. (1977). Essays on Performance Theory (1970-1976). New York: Drama Book Specialists, 212.

[11] Khabermas, Yu. (1982). Ponyatie individualnosti. Voprosy filosofii, 2, 35-40.

[12] Kheyzinga, Y. (1997). Homo Ludens; Stati po istorii kultury. Moscow: Progress-Traditsiya, 416.

[13] Shiller, F. (2016). Pisma ob esteticheskom vospitanii cheloveka. Ripol Klassik, 242. Available at: https://www.yakaboo.ua/ pis-ma-ob-jesteticheskom-vospitanii-cheloveka.html\#tab-attributes

[14] Gesse, G. (1969). Igra v biser. Moscow: Khudozhestvennaya literatura. Available at: http://ib.ru/GESSE/biser.txt

[15] Delez, ZH. (2004). Peregovory. 1972-1990. Saint Petersburg: Nauka, 235.

[16] Debord Guy. La societé du spectacle. Available at: http://sami.is.free.fr/Oeuvres/debord_societe_spectacle_1.html

[17] Goffman, E. (1959) The Presentation of Self in Everyday Life. University of Edinburg Social Sciences Research Center, 162.

[18] Lipovetsky, M. (2010) Charms of the Cynical Reason: Tricksters in Soviet and Post-Soviet Culture (Cultural Revolutions: Russia in the Twentieth Century). Boston: Academic Studies Press, 300. doi: http://doi.org/10.2307/j.ctt21h4wjt

[19] Lotman, Yu. M. (1992). Teatr i teatralnost v stroe kultury nachala XIX veka. Izbrannye stati. Vol. 1. Tallinn: Aleksandra, 269-286.

[20] Bakanurskiy, A. G. (2013). Zhizn, igra, teatralnost: issledovanie v trekh aktakh s prologom i epilogom. Kherson: Grin D.S., 318.

[21] Chmil, H. P., Korablova, N. S. (2013). Vizualizatsiia realnoho v suchasnomu kulturnomu prostori. Kyiv: Instytut kulturolohii NAMU, 256.

[22] Olyanich, A. V. (2015). Teatralnost kak kategoriya politicheskogo diskursa. Diskurs-Pi, 2, 176-178.

[23] Prokopovych, L. (2019). Socio-philosophical foundations of theatricalization of the political sphere. Scientific and Theoretical Almanac Grani, 22 (2), 48-58. doi: http://doi.org/10.15421/171922

[24] Ivanova, S., Dimitrov, L., Ivanov, V., Prokopovych, L. (2021). Using role-playing game for professional skills formation of prospective teachers. society. integration. education. Proceedings of the International Scientific Conference, 1, $195-206$. doi: http://doi.org/10.17770/sie2021vol1.6180

[25] Prokopovich, L. V. (2019). Theatricality of sportsin the socio-philosophical understanding. Scientific Journal "Virtus", $35,40-44$.

[26] Korotkova, M. V. (2018). Teatr i muzey: ispolzovanie priemov teatralizatsii v kulturno-obrazovatelnoy deyatelnosti muzeya. Nauka i shkola, 4, 128-132.

[27] Prokopovych, L. (2019). Human in the new, biotechnocybernetic, "theater" of being. Scientific and Theoretical Almanac Grani, 22 (7), 21-29.

[28] Prokopovych, L. V. (2018). Doslidzhennia henezysu teatru ta teatralizatsii zhyttia yak fenomeniv yevropeiskoi kultury. Euroe pean philosophical and historical discourse, 4 (3), 112-117.

[29] Melik-Gaykazyan, I. V. (2013). Memory turn: proyavlennaya bioetikoy brennost intellektualnykh traditsiy. Idei i idealy, $1(15), 49-63$.

[30] Oslon, A. (2006). Obraz buduschego v sotsialnoy realnosti. Sotsialnaya realnost. Zhurnal sotsiologicheskikh nablyudeniy i soobscheniy, 11, 4-10.

How to cite. Prokopovych, L. (2021). Reflecting the theatralization of life in the prospects of transhumanism. EUREKA: Social and Humanities, 4, 3-8. doi: http://doi.org/10.21303/2504-5571.2021.001972 